\title{
Impacts of Horticultural Mineral Oils and Two Insecticide Practices on Population Fluctuation of Diaphorina citri and Spread of Huanglongbing in a Citrus Orchard in Sarawak
}

\author{
Stephen Chan Teck Leong, ${ }^{1}$ Fatimah Abang, ${ }^{2}$ Andrew Beattie, ${ }^{3}$ \\ Roland Jui Heng Kueh, ${ }^{1}$ and Sing King Wong ${ }^{1}$ \\ ${ }^{1}$ Faculty of Agriculture and Food Sciences, Universiti Putra Malaysia Campus Bintulu Sarawak, Jalan Nyabau, \\ 97008 Bintulu, Sarawak, Malaysia \\ ${ }^{2}$ Faculty of Resource Science and Technology, Universiti Malaysia Sarawak, 94300 Kota Samarahan, Sarawak, Malaysia \\ ${ }^{3}$ Centre for Plant and Food Science, University of Western Sydney, Locked Bag 1797, Penrith New South Wales 2751, Australia
}

Correspondence should be addressed to Stephen Chan Teck Leong, sctleong@btu.upm.edu.my

Received 11 November 2011; Accepted 1 February 2012

Academic Editor: Aurelio Gómez-Cadenas

Copyright (C) 2012 Stephen Chan Teck Leong et al. This is an open access article distributed under the Creative Commons Attribution License, which permits unrestricted use, distribution, and reproduction in any medium, provided the original work is properly cited.

\begin{abstract}
Aspects of the incidence and spread of the citrus disease huanglongbing (HLB) in relation to the vector Diaphorina citri population fluctuation were studied from January 1999 to December 2001 seasons in a 0.8 ha citrus orchard at Jemukan $\left(1^{\circ} 33^{\prime} \mathrm{N}, 110^{\circ} 41^{\prime} \mathrm{E}\right)$, Southwest Sarawak in Malaysia. In relation to insecticide and horticultural mineral oils (HMOs) use, levels of HLB infection rose quite rapidly over the next 3 years in the unsprayed control and less rapidly in the other treatments such as imidacloprid, $n \mathrm{C} 24 \mathrm{HMO}$, and triazophos/cypermethrin/chlorpyrifos. Levels of HLB as determined by Polymerase Chain Reaction (PCR) were $42.2 \%, 9.4 \%, 11.4 \%$, and $22.7 \%$, respectively. The effects of $n \mathrm{C}_{24} \mathrm{HMO}$ and conventional pesticides on the citrus psyllid population and parasitoids in citrus orchard were also determined.
\end{abstract}

\section{Introduction}

The Asiatic citrus psyllid, Diaphorina citri Kuwayama (Hemiptera: Psyllidae), is widely distributed in the Oriental realm [1]. D. citri achieved major pest status when it was identified as the vector of Huanglongbing (HLB) or citrus greening disease (CGD) caused by Candidatus Liberibacter asiaticus ( $\alpha$-Protobacteria) [2] in Asia [3-8]. The distribution of $D$. citri is wider than that of the citrus greening bacterium, the major pathogen which transmits $D$. citri is very prolific and efficient vector of HLB [9], and its activity is the key to HLB spread. HLB is one of the most serious and devastating disease of citriculture in the world $[7,8,10,11]$, having destroyed around 50 million citrus trees since it was observed in China by Reinking [12], with most of these losses occurring in Southeast Asia [13]. HLB is currently found in China, Taiwan, Thailand, Vietnam, the Philippines, Indonesia, New Guinea; Japan and other major citrus growing areas in South Africa, USA, India, Pakistan, and
Reunion Island, Brazil [14-20]. It is the greatest hindrance to the commercial development of viable citrus industries in tropical and subtropical Asia [21]. As a consequence, the income of farmers and national economies are seriously affected.

In Malaysia, D. citri was first recorded in Ringlet, Cameron Highland and Ulu Tiram, Johor in 1978 [22], and symptoms of HLB were first noticed in Malaysia in the 1970s [23, 24], and its presence was confirmed in 1989 [25]. HLB together with its vector is now widely distributed in the lowlands and has been recorded in many parts of the country [26]. It has spread rapidly and gained national importance owing to the dramatic spread and transmission of HLB between 1989 and 1992 in Malaysia, which devastated citrus orchards in Peninsular and East Malaysia, including Sarawak $[26,27]$. The once flourishing citrus industry in the Samarahan Division of Southwest Sarawak in Malaysia was completely destroyed by HLB in 1992 [27]. By 1991, 
the disease had destroyed a total area of 1,143 ha with more than 309,500 trees resulting in an estimated yield loss of more than 6,500 metric tons of fruit and an economic loss of RM 6.5 million [27, 28]. HLB and its vectors pose a major threat to the Malaysian citrus and nursery industries, especially in citrus rehabilitation. Furthermore, HLB is a highly destructive and fastidious disease of citrus. It is the primary cause of losses in citrus production in Asia [14], South Africa, and USA [20], and there is no successful treatment of infected trees. The development of sustainable management practices for minimizing the impact of HLB and its vector control options include the use of mineral oils, imidaclorprid, removal of alternate host plants for the disease and vector-near citrus orchard, removal of diseased trees, introduction of trees as wind breakers, rotation plantings and interplanting with a nonhost such as guava (Psidium guajava) can effectively reduce the incidence of $D$. citri and HLB in citrus orchards has been reported by some researchers [29-31]. Current controls of HLB in Sarawak are limited to the use of disease-free propagating stock, elimination of infected trees, and chemical control of $D$. citri. Ko [23] mentioned that sprays were required at least fortnightly in Malaysian orchards for control of D. citri, and more frequent applications were required during periods of flush growth. Current management strategies in Brazil involve annual application of some 8-18 sprays to trees less than 4-year-old [32]. Some researchers such as Tiwari et al. [20] reported the emerging insecticide resistance problem for Asian citrus psyllid if effective resistance management is not practiced. HLB is a devastating disease and not curable at present with chemical control. As such an integrated disease and vector management must be implemented. The studies on transmission, spread, and control of the HLB vector are relevant to the severity and urgency of the problem to the citrus and nursery industries in Malaysia and other major citrus growing areas. In this study, we report the incidence and spread of HLB in relation to the development and dispersal of $D$. citri population and their possible vector control in a citrus orchard.

\section{Materials and Methods}

2.1. Incidence and Spread of D. citri Population in a Citrus Orchard. Field studies conducted from January 1999 to December 2001 in a 0.8 ha citrus orchard at Jemukan $\left(1^{\circ}\right.$ $\left.33^{\prime} \mathrm{N}, 110^{\circ} 41^{\prime} \mathrm{E}\right)$, Samarahan Division, Southwest Sarawak in Malaysia were focused on seasonal population changes, migration, and dispersal of $D$. citri as to detect changes in the incidence of vector and spread of citrus HLB in the citrus orchard and the impacts of the pesticides and horticultural mineral oils on the vector and its primary parasites. It comprised 200 initially disease-free, bud-grafted, honey mandarin plants (Citrus x C. aurantium Linnaeus) [Rutaceae: Aurantioideae] planted in 1999. Disease-free trees were used to establish the citrus orchard in which the study was based.

A total of 100 flushes were selected on each sampling date. Visual counts were taken on the number of psyllids (eggs, nymph, and adults) on the five twigs (each 10 to $20 \mathrm{~cm}$ long) per tree. All young shoot samples were about 6 to $10 \mathrm{~cm}$ long and had 5 immature leaves within the size range 2 to $4 \mathrm{~cm}$ long. Insect count and number of trees infested by psyllids were recorded weekly throughout citrus growing season.

2.2. Disease Incidence and Spread of $H B L$ in relation to Psyllid Population. Incidence of HLB was monitored by visual inspection for signs of characteristic symptoms such as yellowing shoots, leaf mottling, and blotching. The number of HLB suspected trees in the orchard based on the visual symptoms was calculated monthly. Disease incidence was calculated as the number of trees expressing symptoms divided by the total number of trees in the orchard. Monthly samples of leaf midveins were collected on presumably infected trees, and field diagnosis was subsequently confirmed on the diseased trees. A molecular diagnostic technique, Polymerase chain reaction (PCR) procedures that amplify rDNAs fragments using HLB-specific primer $16 \mathrm{~S}$ rDNA was used to confirm the presence of the bacterium in diseased trees.

\subsection{Effects of Horticultural Mineral Oils and Conventional} Pesticides on Oviposition, Nymphs, and Adult Mortality. The pesticide efficacy experiment had 4 treatments with 4 replicates arranged in a randomized complete block design. Each replicate comprised of 12 trees, and assessments were based on 6 central trees in each replicate. Other trees in each plot were used as spray drift buffers. The 4 treatments were (a) a control, unsprayed, (b) $n \mathrm{C} 24$ horticultural mineral oils (HMOs) (Ampol D-C Tron Plus: Ampol Rural, Sydney, Australia) applied as $0.35 \% \mathrm{v} / \mathrm{v}$ aqueous emulsions, (c) a conventional synthetic pesticide based on applications of triazophos $(0.03 \%)$ (Hostathion 40EC, Aventis Crop Science), alternated with cypermethrin $(0.125 \%)$ (Dow Agro Science) and chlorpyrifos (0.0125\%), and (d) applications of a systemic neonicotinoid insecticide imidaclorprid $(0.01 \%)$ (Confidor 200EC, Bayer, Selangor Darul Ehsan, Malaysia).

A motorised Fuji FP-25 knapsack sprayer was used to apply HMO at $0.35 \%(\mathrm{v} / \mathrm{v})$ thoroughly to run off every 6 to 7 days and particularly during the annual flushing periods occurred in February-March, July, and September-October and the volumes applied per tree increased as the trees grew. The specifications of the HMO were given by Rae et al. [33]. All other pesticides were applied biweekly at the manufacturers' recommended rates.

2.4. Statistical Analysis. Data was subjected to one-way analysis of variance (ANOVA). The NCSS computer package was used for the ANOVA. For significant $F$ values, the differences between the means were separated using the Fisher's least significant difference test at $P \leq 0.05$.

\section{Results and Discussion}

3.1. Incidence and Spread of D. citri Population in a Citrus Orchard. Figure 1 indicates that a higher percentage of untreated trees are related to a higher numbers of adult 


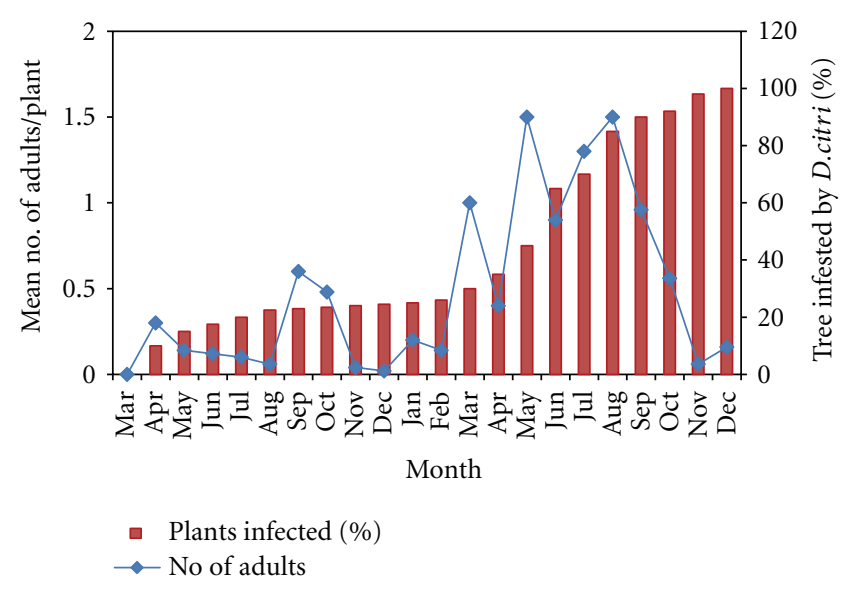

FIgURE 1: Incidence and spread of $D$. citri population in a citrus orchard at Jemukan.

psyllids. The value increased from $1.5 \%$ of trees infested to $46.0 \%$ one year after the first infestation was observed, and this value had jumped to $90 \%$ of trees infested 5-6 months later. It took about one year and nine months to infest all trees in the untreated citrus orchard. There was a linear increase in the number of trees becoming infested relative to time $(r=0.983, P<0.001)$, and migration/dispersal of the psyllid population was mainly related to the main flush cycles occurred in February-March and September-October. The spread of $D$. citri from tree to tree throughout the growing seasons will result in the increase in the number of trees became infested in a citrus orchard as shown in Figure 1. The rapid build-up in D. citri population resulted from the exponential population growth and migration or dispersal of the psyllid population was mainly related to main flush cycles. This clearly indicates that the build-up in D. citri population was greatly influenced by the young flush growth, and the increase in populations of nymphs and eggs was greater than the adults in the citrus trees. This implies that a higher nymph numbers will become adults and subsequently result in a high adult population. The rate of infestation from tree to tree was not calculated, but Samways and Manicom [34] found that when T. erytreae invaded an orchard and its populations increased exponentially, the rate new trees became infected increased by $4 \%$ per day in an unsprayed orchard.

\subsection{Disease Incidence and Spread of HBL in relation to Psyllid} Population. Figures 2(a) and 2(b) show percentage of HLB incidence on control and treated trees in citrus orchard. The percentage of infected trees increased progressively from $10 \%$ on 7th April 1999 to $38.7 \%$ on 6th August 1999 in the untreated control plots; only $2.4 \%$ of these plants gave positive PCR results (7th April 1999). By 10th April $2000,19.2 \%$ out of the $56.2 \%$ of plants with symptoms of mild mottling and small leaves pointing upright gave positive PCR results. By October 2001, 80.2\% of trees in the study orchard exhibited typical visual symptoms of the disease; within four years after planting $42.2 \%$ of trees in the unsprayed plots were infected (Figures 2(a) and 2(b)). The increase in incidence and spread of HLB in the citrus orchard was because of the high vector populations due to migration and/or dispersal of infective adults and their spread from infected trees to healthy trees during the flushing periods (February-March, July and September-October). The imidaclorprid and HMO-treated plots produced a lower percentage $(9.4 \%$ and $11.4 \%)$ of diseased plants as compared with $22.7 \%$ in triazophos/cypermethrin/chlorpyrifostreated plots (Figure 2(b)). The HMO treatment produced a lower percentage $(11.4 \%)$ of diseased plants as compared with $42.2 \%$ in untreated control trees. The percentage of infested trees was greatly reduced in the sprayed plots as compared with unsprayed plots. This may attribute to the impact of HMO on the feeding behaviour of the psyllids and suffocation of nymphs and reduced oviposition due to behavioural effects on adult females and spray may have caused significantly adult mortality. Ingress of HLB was slower than untreated control in the experiment with imidacloprid reported by Gatineau et al. [35], in which the levels of HLB infection (symptomatic and PCR + ) reached $24 \%$ and $74 \%$, respectively, within 2 years and $96 \%$ in the untreated control. In China, citrus HLB often spread quickly in young citrus orchards; $50-70 \%$ of the citrus trees were infected before fruit production [36].

Certain mineral oils are known to reduce aphid colonization on plants, and thus the transmission of virus disease [37]. Vandenveken [38] further suggested that the oils might modify the charge of the stylet, thus impeding adsorption or elusion of virus particles, or the inhibitory properties of oils would hamper the exchange of charge between virus particles, aphid mouthparts, and plant cells. Clearly, the vector control programs practiced in this orchard did not prevent establishment and spread of HLB. The spread of disease in the D. citri-infested citrus orchard or transmission appears to be related to high vector populations and extensive inoculum reservoir [38]. Psyllid movement is highest when host plants are flushing and T. erytreae is reported to be highly infective on young flush [39]. Therefore, the prolong flushing during the flush cycles of young trees made them very attractive to the vector, and this can partly explain the rapid spread of disease in the psyllid infested trees within the citrus orchard. Schwarz et al. [40] showed a positive correlation between the degree of greening infection, the number of psyllids, and the rate of transmission. Psyllids are strongly attracted by yellow green of wavelength $550 \mathrm{~nm}$ [41], and making the diseased trees attractive target and thereby increasing the proportion of disease-carrying insects. Koizumi et al. [42] demonstrated that field collected psyllids were able to transmit HLB at a rate of at least $41 \%$ after 2 days of feeding. DNA hybridisation revealed that the proportions of viruliferous psyllids found in the infested citrus orchard in May and September ranged from $5 \%$ to $39 \%$, respectively, in Sarawak [4]. These facts suggest that elimination of the pathogen is not possible in the absence of effective programs for removing diseased trees. Obviously $D$. citri was responsible for the rapid spread of HLB from trees to trees over time within the orchard. Gibson et al. [43] and Rice et al. [44] suggested that the insecticides 


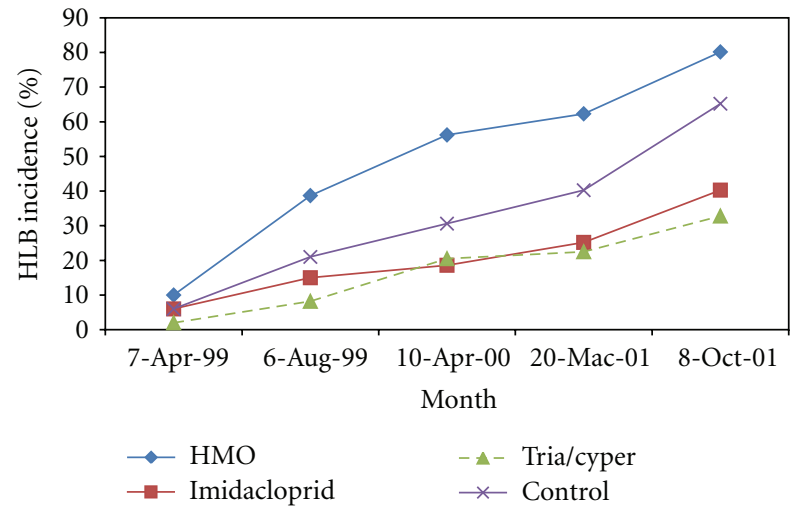

(a)

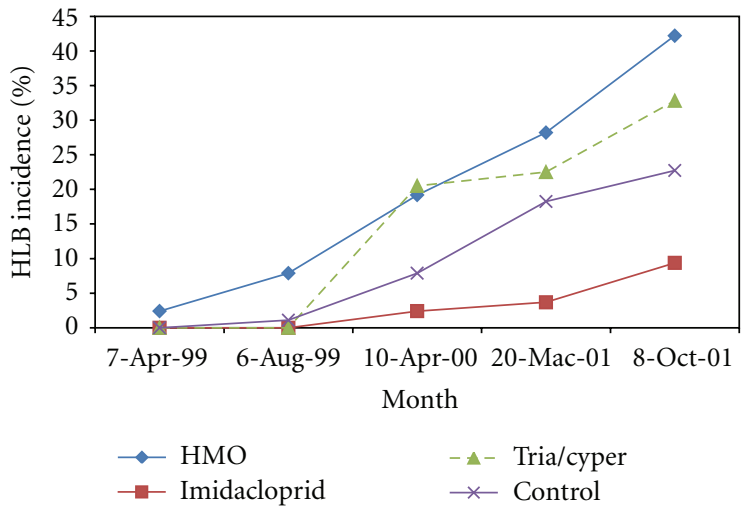

(b)

Figure 2: (a) Percentage of HLB-symptomatic infected trees on control and treated citrus orchard at Jemukan. (b) Percentage of HLB diseased trees on control and treated citrus orchard at Jemukan.

with highly selective activity on insect and its natural enemies used to inhibit virus disease transmission should cause rapid know-down and prolonged incapacitation of the insect. Applying insecticides at critical flushing periods may be effective to some degree in reducing spread of disease and may require regular monitoring of citrus in order for time management strategies such as insecticide applications.

\subsection{Effects of HMO and Conventional Pesticides on Ovipo-} sition, Nymphs, and Adult Mortality. The number of female psyllids landing on flushes differed significantly between treatments $(P \leq 0.01)$, but there were no differences between the unsprayed control and the triazophos/cypermethrin/chlorpyrifos treatment, or between the imidaclorprid and HMOs treatments (Figure 3). For eggs, there was a significant difference between treatments $(P \leq 0.01)$ for the percentage of flush on which eggs were laid; all spray treatments significantly reduced the number of flushes on which eggs were laid. Although more eggs were laid on unsprayed flushes than in the HMO treatment, there was no significant difference between treatments for the number of eggs laid per flush (Figure 3 ).

The mean number of nymphs and adults per flush was significantly reduced by all treatments (Figure 3 ). The mean number of nymphs and adults per flush was significantly reduced by all treatments (Figure 3). The HMO and imidaclorprid treatments were the most effective treatments for preventing adult females from landing on flushes (Figure 3). This outcome may have important implications for transmission of HLB, as it suggests that in these treatments the level and extent of feeding by adults would have been significantly less than the triazophos/cypermethrin/chlorpyrifos and unsprayed control treatment, and therefore transmission of the disease would have been less. All treatments did not affect the landing of female psyllids on sprayed flushes. Since the percentage of flushes landed on by female psyllids and percentage of flushes on which eggs were deposited in the HMO and imidaclorprid treatments were significantly lower than in the triazophos/cypermethrin/chlorpyrifos and

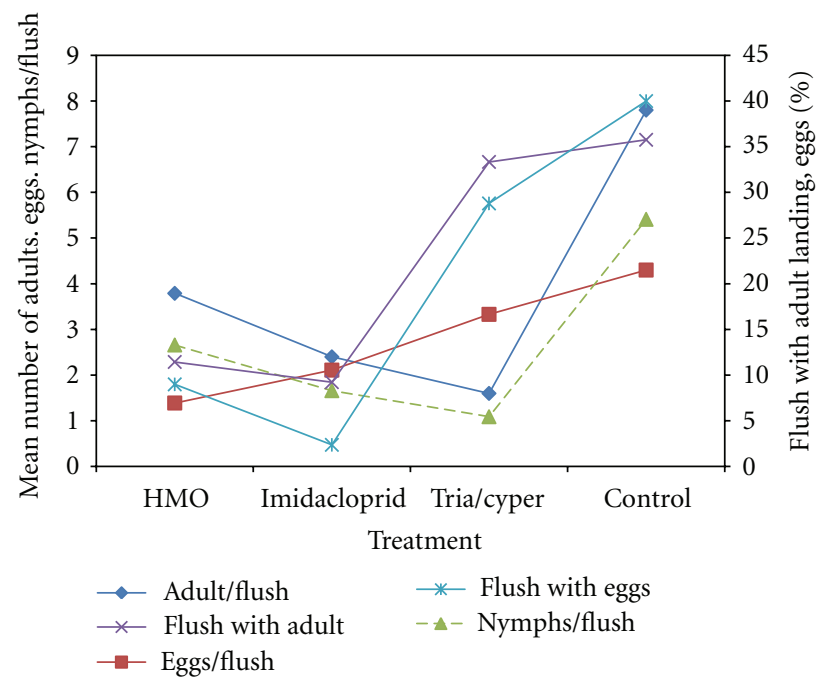

Figure 3: Effects of treatments on D. citri infestations on flush growth during August 2000.

unsprayed treatments (Figure 3), and because female psyllids were equally likely to land on sprayed and unsprayed flushes, the deposition of fewer eggs on sprayed flushes indicates that $\mathrm{HMO}$ and imidaclorprid sprayed flushes were discriminated against. This study clearly demonstrates that HMO and imidaclorprid reduced the number of eggs deposited by female psyllids and are presumably the result of oviposition deterrence. Oviposition deterrence as a result of oil deposits has also been demonstrated with Asiatic citrus psyllid [29, 30, 45], citrus leaf miner [33], codling moth, and whiteflies. The impact of the HMO on D. citri (see Figure 3 ) was attributed to suffocation of nymphs and reduced oviposition due to behavioural effects on adult females. Sprays may also have caused significantly adult mortality. The effect of imidaclorprid was higher than HMO in reducing the female psyllids per flush and the percentage of flush with eggs deposited on sprayed flushes probably because it is a systemic 


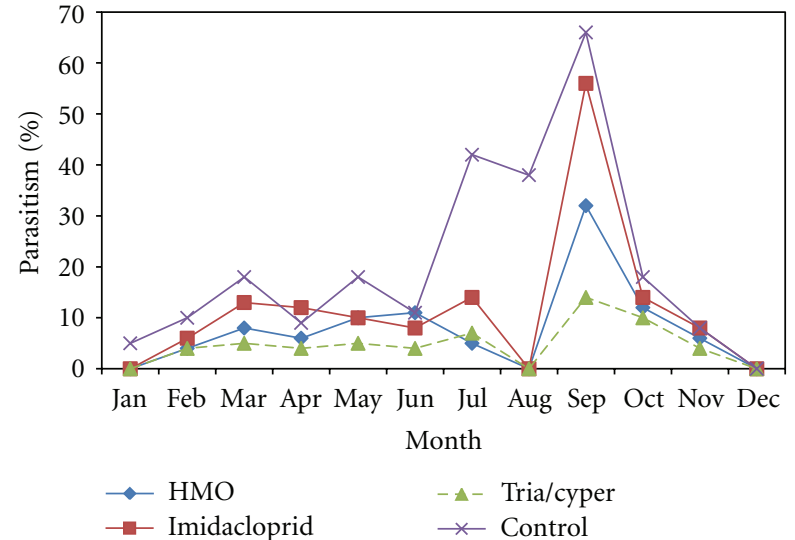

(a)

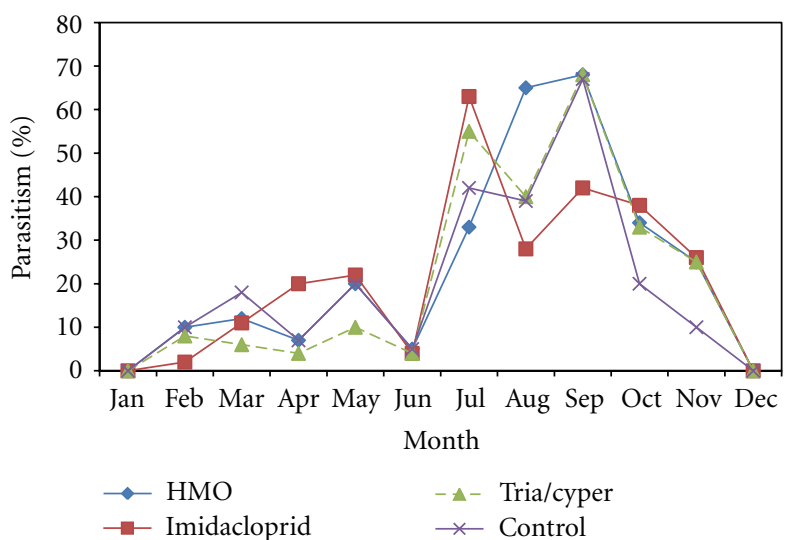

(b)

FIGURE 4: (a) Effect of treatments on percentage of parasitism on D. citri nymphs by T. radiata in a citrus orchard. (b) Effect of treatments on percentage of parasitism on D. citri nymphs by D. aligarhensis in a citrus orchard.

neonicotinoid insecticide and acts as a contact and stomach poison against psyllid.

3.4. Effects of HMO and Conventional Pesticides on Field Parasitism of D. citri Nymphs. Regular field application of insecticides can directly reduce the number of $D$. citri nymphs available for parasitism. Despite the applications of insecticides treatments, the two primary parasitoids Tamarixia radiata (Waterston) [Hymenoptera: Eulophidae] or Diaphorencyrtus aligarhensis [46] [Hymenoptera: Encyrtidae] were still able to parasitise $D$. citri nymphs and complete their development. This implies that if an insecticide spray fails to kill all $D$. citri nymphs, then either parasitoid may be able to attack the survivors. Good potential therefore exists for that use of more selective insecticide, for example, $\mathrm{HMO}$ and imidaclorprid in conjunction with the parasitoids to manage $D$. citri population more effectively. The results (Figures 4(a) and 4(b)) of this study showed that HMO appeared to have less impact on both primary parasitoids than synthetic insecticides. The parasitism rate might be slightly reduced because as parasitoids have to search for hosts within canopies, they inevitably come into contact with sprayed leaf surfaces. Further as a result of the psyllid numbers being reduced more time is spent searching for psyllid. The results suggest an important role for both $T$. radiata and D. aligarhensis, the two parasitoids in IPM programs for $D$. citri, particularly those based on selective products such as HMO and imidaclorprid. In summary, the results showed that both imidaclorprid and HMO could be used as key components in integrated pest and disease management program for sustainable control of $D$. citri. Further research may be warranted to determine if the number of sprays required annually can be minimised in relation to the phenologies of $D$. citri and its plant hosts.

\section{Conclusion}

There was a linear increase in the number of trees becoming infested relative to time within the citrus orchard, and migration and dispersal of the adults was also related to flushing cycles. The HMO and imidaclorprid treatments were the most effective treatments for preventing adult females from landing on flushes. The percentage of infested trees was greatly reduced in the sprayed plots as compared with unsprayed plots. There is an important role for both T. radiata and $D$. aligarhensis, in IPM programs for $D$. citri, particularly those based on selective products such as HMO and imidaclorprid.

As for all insect-borne diseases, the aim is to reduce vector populations and their contact with infected host plants. In tropical humid areas like Malaysia, control of $D$. citri population requires the use of pesticides, particularly in time when conditions favour its development. The prevention of high psyllid populations especially during the flushing cycle is extremely important in checking the spread of the disease. Thus, insecticide sprays must target at these young growth flushes. It is very important to protect citrus trees from HLB infection when they are young. The focus on killing the psyllids in order to limit the spread of HLB has led to emphasis being placed on reducing their impact by minimizing feeding by adults and oviposition.

A successful IPM programme for HLB and its vector in individual orchard is achieved by combining proper nursery management with early eradication of all infected and uneconomic trees, use of healthy planting materials, and effective control of psyllid vector by judicious insecticidal spray schedule supplemented with natural enemies.

\section{Acknowledgement}

This study was supported by the Australian Center for International Agricultural Research (ACIAR).

\section{References}

[1] I. D. Hodkinson and J. M. White, "The neotropical Psyllidae. (Homoptera: Insecta) an annoted check list," Journal Natural History, vol. 15, pp. 491-523, 1981. 
[2] S. Jagoueix, J. M. Bove, and M. Garnier, "The phloem-limited bacterium of greening disease of citrus is a member of the $\alpha$ subdivision of the Proteobacteria," International Journal of Systematic Bacteriology, vol. 44, no. 3, pp. 379-386, 1994.

[3] J. M. Bove, E. C. Calavan, S. O. Capoor, R. E. Cortez, and R. E. Schwarz, "Influence of temperature on symptoms of California Stubborn, South African greening, Indian decline and Philippines leaf mottle," in Proceedings of the 6th Conference International Organization of Citrus Virologists, V. J. Da Graca, P. Moreno, and K. R. Yokimi, Eds., pp. 12-15, Calif, USA, 1974.

[4] J. M. Bove, M. Garnier, Y. S. Ahlawat, N. K. Charkraborty, and A. Varma, "Detection of the Asian strains of the greening BLO by DNA-DNA hybridization in Indian orchard trees and Malaysian Diaphorina citri psyllids," in Proceedings of the 12th Conference International Organization of Citrus Virologists, J. V. Da Graca, P. Moreno, and R. K. Yokimi, Eds., pp. 258-263, Calif, USA, 1992.

[5] H. D. Catling, "Distribution of the psyllid vectors of citrus greening disease with notes on the biology and bionomics of D. citri Kuw," FAO Plant Protection Bulletin, vol. 18, pp. 8-15, 1970.

[6] Y. D. Pande, "Biology of citrus psylla, Diaphorina citri Kuw. (Hemiptera: Psyllidae)," Israel Journal Entomology, vol. 6, pp. 307-311, 1971.

[7] J. H. Tsai, Z. Y. Chen, C. Y. Shen, and K. X. Jin, "Mycoplasmas and fastidious vascular prokaryotes associated with tree diseases in China," in Tree Mycoplasmas and Mycoplasma Diseases, C. Hiruki, Ed., pp. 69-240, The University of Alberta Press, Edmonton, Canada, 1988.

[8] B. Aubert, M. Grisono, M. Villemin, and G. Rossolin, "A case study of huanglongbing (greening) control in Réunion," in Proceedings of the 13th Conference IOCV, J. V. Da Graca, P. Moreno, and R. K. Yokimi, Eds., pp. 276-278, Calif, USA, 1996.

[9] C. F. Xu, Y. H. Xia, K. B. Li, and C. Ke, "Further study of the transmission of citrus huanglongbin by psyllid, Diaphorina citri Kuwayama," in Proceedings of the FAO-UNDP Regional Workshop on Citrus Greening Huanglongbin Disease, p. 10, Fuzhou, China, December 1987.

[10] B. Aubert, "Citrus greening disease, a serious limiting factor for citriculture in Asia and Africa," in Proceedings of the 4th World Congress of International Society of Citrus 1993, R. Etienne, Ed., pp. 134-142, Nurserymen, South Africa.

[11] H. J. Su and A. L. Huang, "The nature of Likobia organism, life cycle, morphology and possible strains," in Proceedings of the Conference, UNDP_FAO Regional Project for Citrus Greening Control, pp. 106-110, 1990.

[12] O. A. Reinking, "Disease of economic plants in Southern China," Philippine Agriculture, vol. 8, pp. 109-135, 1919.

[13] B. Aubert, "Malaysian citriculture report of visits October 19th-22nd 1987 and February 23rd-28th 1989," Tech. Rep., 1989.

[14] B. Aubert, "Integrated activities for the control of huanglongbing-greening and its vector Diaphorina citri Kuwayama in Asia," in Proceedings of the 4th International Asia-Pacific Conference on Citrus Rehabilitation, UNDP-FAO, B. Aubert, S. Tontyaporn, and D. Buangsuwon, Eds., pp. 133-144, Chiang Mai, Thailand, February 1990.

[15] J. V. Da Graca, "Citrus greening disease," Annual Review of Phytopathology, vol. 29, pp. 109-136, 1991.

[16] M. Garnier and J. M. Bove, "Distribution of the huanglongbing (greening) Liberobacter species in fifteen African and Asian countries," in Proceedings of the 13th Conference of the International Organization of Citrus Virologists, J. V. Da Graca,
P. Moreno, and R. K. Yokomi, Eds., pp. 388-391, Riverside: International Organization of Citrus Virologists, University of California, Fujian, China, November 1995.

[17] M. P. Weinert, S. C. Jacobson, J. F. Grimshaw et al., "Detection of Huanglongbing (citrus greening disease) in Timor-Leste (East Timor) and in Papua New Guinea," Australasian Plant Pathology, vol. 33, no. 1, pp. 135-136, 2004.

[18] S. Halbert, "The discovery of huanglongbing in Florida," in Proceedings of the 2nd International Citrus Canker and Huanglongbing Research Workshop, no. H-3, p. 50, Orlando, Fla, USA, November 2005.

[19] S. A. Lopes, R. B. BassaneziJr. Belasquej, and P. T. Yamamoto, "Management of citrus huanglongbing in the State of São Paulo-Brazil," in Proceedings of the FFTC-PPRI-NIFTS Joint Workshop on Management of Citrus Greening and Virus Diseases for the Rehabilitation of Citrus Industry in the ASPAC, T. Y. Ku and T. H. H. Pham, Eds., pp. 107-117, PhamPlant Protection Research Institute, Hanoi, Vietnam, September 2008.

[20] S. Tiwari, R. S. Mann, M. E. Rogers, and L. L. Stelinski, "Insecticide resistance in field populations of Asian citrus psyllid in Florida," Pest Management Science, vol. 67, pp. 12581268, 2011.

[21] B. Aubert, "High density planting (HDP) of Jiaogan mandarin in the lowland area of shantou (Guangdong China) and implications for greening control," in Proceedings of the 4th International Asia-Pacific Conference on Citrus Rehabilitation, UNDP-FAO, B. Aubert, S. Tontyaporn, and D. Buangsuwon, Eds., pp. 149-157, Chiang Mai, Thailand, February 1990.

[22] A. Yunus and T. H. Ho, "List of economic pests, host plants, parasites and predators in W. Malaysia (1920-1978)," Ministry of Agriculture Bulletin, no. 153, 1980.

[23] W. W. Ko, "Plant indexing to detect the greening disease in Malaysia," in Proceedings of the 2nd Asian/Pacific Regional Workshop on citrus greening, B. Aubert, C. Ke, and C. Gonzales, Eds., pp. 84-86, UNDP-FAO, Lipa, Philippines, November 1988.

[24] W. W. Ko, "Citrus diseases in Malaysia," in Proceedings of the 6th International Asia Pacific Workshop on Integrated Citrus Health Management, C. Ke and S. B. Osman, Eds., pp. 147162, Kuala Lumpur, Malaysia, June 1991.

[25] W. H. Lim, O. M. Shamsudin, and W. W. Ko, "Citrus greening disease and alternate hosts of the vector, Diaphorina citri Kuw. in P. Malaysia," MAPPS Newsletter (The Newsletter of the Malaysian Plant Protection Society), vol. 13, no. 4, pp. 56-58, 1990.

[26] W. H. Lim, O. M. Shamsudin, and W. W. Ko., "Citrus greening disease in Malaysia: status report," in Proceedings of the 4th International Asia Pacific Conf. on Citrus Rehabilitation, B. Aubert, S. Tontyaporn, and D. Buangsuwon, Eds., pp. 100105, FAO UNDP, Chiang Mai, Thailand, February, 1990.

[27] C. H. Teo, B. H. Voon, and C. T. Leong, "Integrated Management of citrus greening disease (Huanglongbing) in Sarawak," in Proceedings of the Plant Resource Management Conference, pp. 29-31, Kuching, Malaysia, 2000.

[28] N. G. Wee, "Development plan on replanting of citrus in 7MP: Mechanics, physical and financial schedule," in Proceedings of the In-House Mini-Seminar on Citrus Greening Disease Rehabilitation Programme, no. 2, Technology Promotion, Department of Agriculture, Agriculture Institute Semongok, June1996.

[29] S. C. T. Leong, H. L. Ng, G. A. C. Beattie, and D. M. Watson, "Comparison of a horticultural mineral oil and two pesticidebased programs for control of citrus pests in Sarawak, 
Malaysia," in Proceedings of the Spray Oils Beyond 2000: Sustainable Pests and Disease Management, 25-29 October 1999, Sydney, Australia, G. A. C. Beattie, D. M. Watson, M. L. Stevens, D. J. Rae, and R.N. Spooner-Hart, Eds., pp. 432-443, 2002.

[30] S.C.T Leong, Spread of Huanglongbing, Population Dynamics and Control of Diaphorina citri Kuwayama, the Asiatic Citrus Psyllid in Sarawak, Ph.D. thesis, Faculty of Resource Science and Technology, Universiti Malaysia Sarawak, 2006.

[31] G. A. C. Beattie, P. Holford, D. J. Mabberley, A. M. Haigh, R. Bayer, and P. Broadbent, "Aspects and insights of AustraliaAsia collaborative research on Huanglongbing," 2007.

[32] C. C. Childers and M. E. Rogers, "Chemical control and management approaches of the Asian citrus psyllid, Diaphorina citri Kuwayama (Homoptera: Psyllidae) in Florida citrus," in Proceedings of the Florida State Horticultural Society, vol. 118, pp. 49-53, 2005.

[33] D. J. Rae, G. A. C. Beattie, D. M. Watson, Z. M. Liu, and L. Jiang, "Effects of Petroleum Spray Oils without with Copper Fungicides on the Control of Citrus Leafminer, Phyllocnistis citrella Stainton (Lepidoptera: Gracillariidae)," Australian Journal of Entomology, vol. 35, no. 3, pp. 247-251, 1996.

[34] M. J. Samways and B. Q. Manicom, "Immigration, frequency distributions and dispersion patterns of the psyllid Trioza erytreae (Del Guercio) in a citrus orchard," Journal of Applied Ecology, vol. 20, no. 2, pp. 463-472, 1983.

[35] F. Gatineau, H. T. Loc, N. D. Tuyen, T. M. Tuan, N. T. D. Hien, and N. T. N. Ruc, "Effects of 2 insecticide practices on population dynamics of Diaphorina citri and on huanglongbing incidence in south Vietnam," in Proceedings of the Huanglongbing-Greening International Workshop, Ribeirão Preto, p. 110, São Paulo, Brazil, July 2006.

[36] C. F. Xu, Y. H. Xia, K. B. Li, and C. Ke, "Preliminary study on the bionomics of Diaphorina citri Kuwayama, the vector of citrus huanglungbin disease," in Proceedings of the 2nd FAO-UNDP Regional Workshop, Lipa, Philippines. AsianPacific Citrus Greening, B. Aubert, C. Ke, and C. Gonzales, Eds., pp. 29-31, 1988.

[37] J. N. Simon and T. A. Zitter, "Use of oils to control aphid borne viruses," Plant Disease, vol. 64, pp. 542-546, 1980.

[38] J. J. Vandenveken, "Oils and other inhibitors of nonpersistent virus transmission," in Aphids as Virus Vectors, K. F. Harris and K. Maramorosh, Eds., pp. 435-454, Acadamic Press, New York, NY, USA, 1977.

[39] B. Aubert, "Epidermiological aspects of the greening (Huanglungbing) disease in Asia," in Proceedings of the FAO Regional Workshop on Citrus Greening Huanglungbing Disease, Fuzhou, China, December, 1987.

[40] R. E. Schwarz, A. P. D. McClean, and H. D. Catling, "The spread of greening disease by the citrus psylla in South Africa," Phytophytactica, vol. 2, pp. 59-60, 1970.

[41] M. J. Samways, "Weather and monitoring the abundance of the adult citrus psylla, Trioza erytreae (Del Guercio) (Hom., Triozidae)," Journal of Applied Entomology, vol. 103, pp. 502508, 1987.

[42] M. Koizumi, M. Prommintara, G. Linwattana, and T. Kaisuwan, "Epidemiological aspects of citrus huanglongbing (greening) disease in thailand," Japan Agricultural Research Quarterly, vol. 31, no. 3, pp. 205-211, 1997.

[43] R. W. Gibson, A. D. Rice, J. A. Pickett, M. C. Smith, and R. M. Sawicki, "The effects of the repellents dodecanoic acid and polygodial on the acquisition of non-,semi-and persistent plant viruses by the aphid Myzus persicae," Annal of Applied Biology, vol. 100, pp. 55-59, 1982.

[44] A. D. Rice, R. W. Gibson, and M. F. Stribley, "Effects of deltamethrin on walking, flight and potato virus Y-transmission by pyrethroid-resistant Myzus persicae," Annal of Applied Biology, vol. 102, pp. 229-236, 1983.

[45] D. J. Rae, W. G. Liang, D. M. Watson, G. A. C. Beattie, and M. D. Huang, "Evaluation of petroleum spray oils for control of the Asian citrus psylla, Diaphorina citri (Kuwayama) (Hemiptera: Psyllidae), in China," International Journal of Pest Management, vol. 43, no. 1, pp. 71-75, 1997.

[46] S. A. Shafee, S. M. Alam, and M. M. Agarwal, "Taxonomic survey of encyrtid parasite (Hymenoptera : Encyrtidae) in India," Aligarh Muslim University Publication On Indian Insect Types, vol. 10, pp. 1-125, 1975. 


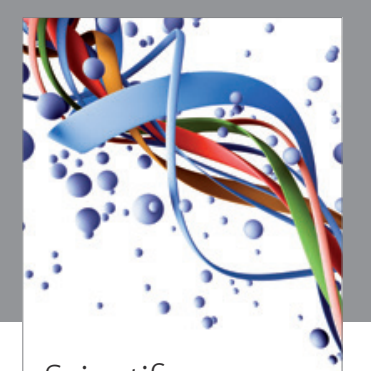

Scientifica
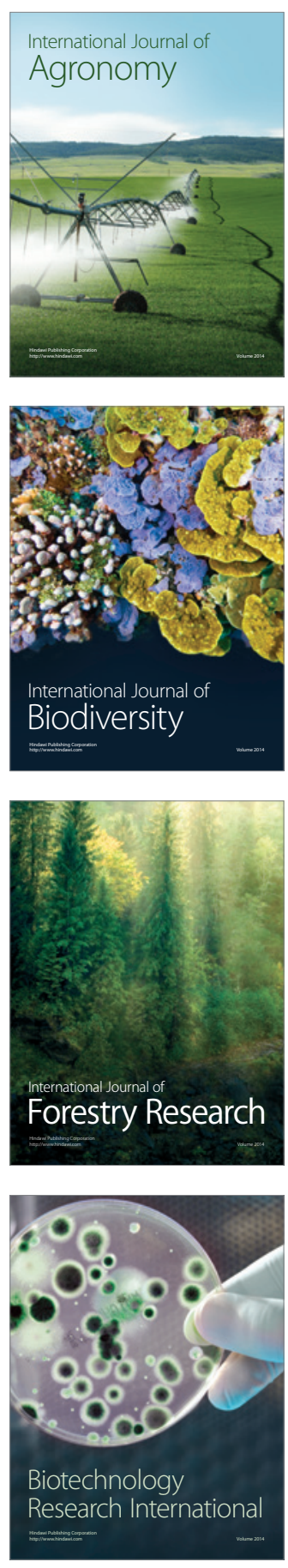
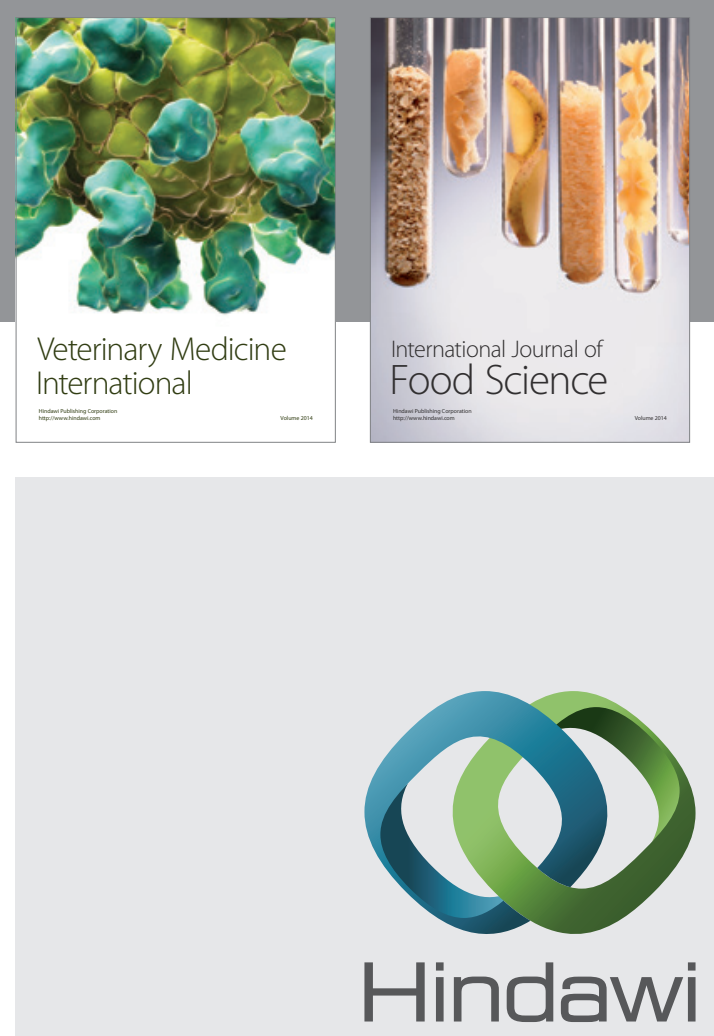

Submit your manuscripts at

http://www.hindawi.com
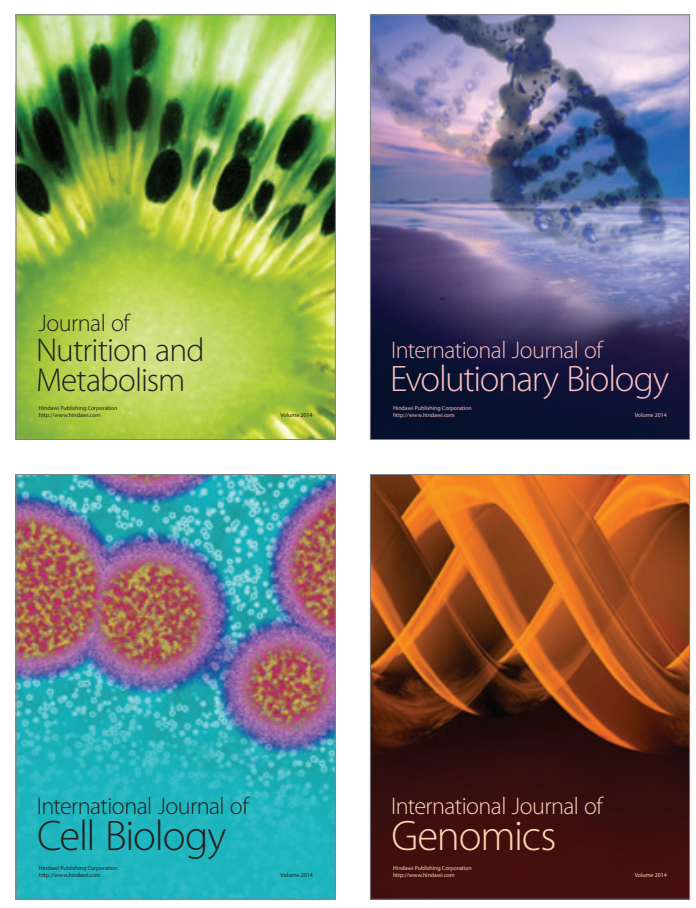
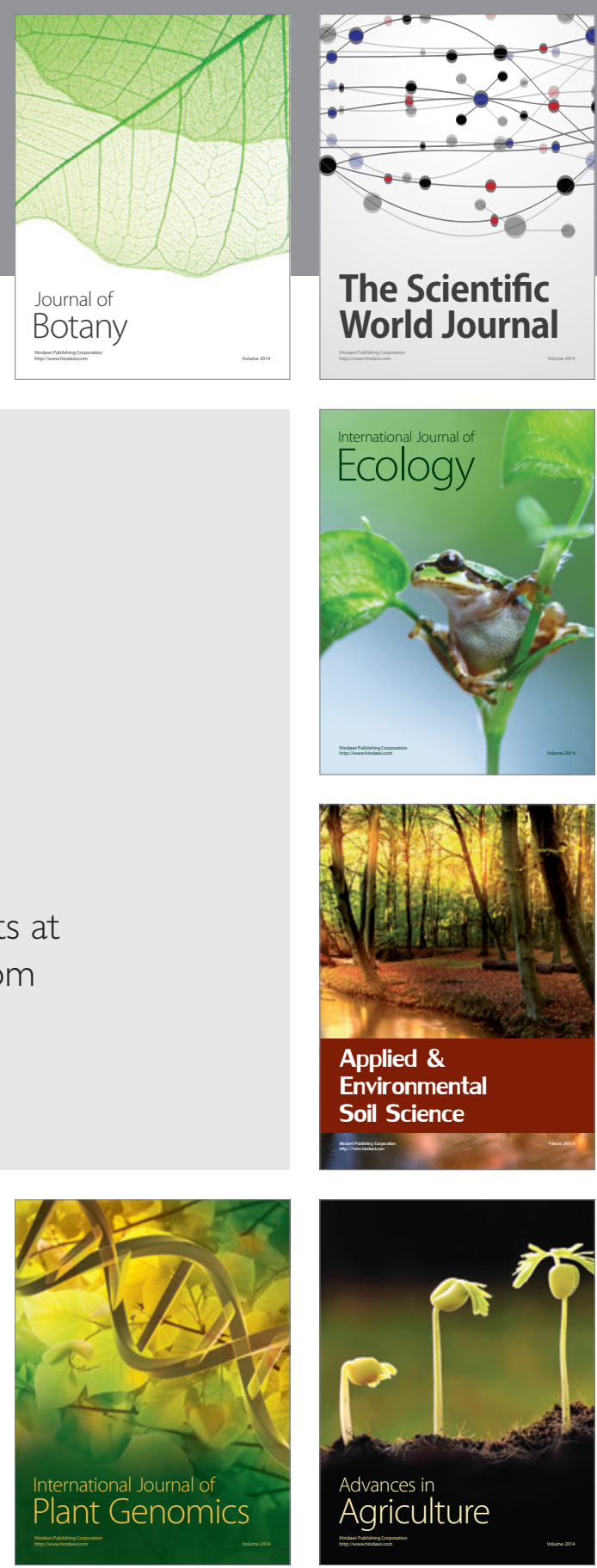

The Scientific World Journal
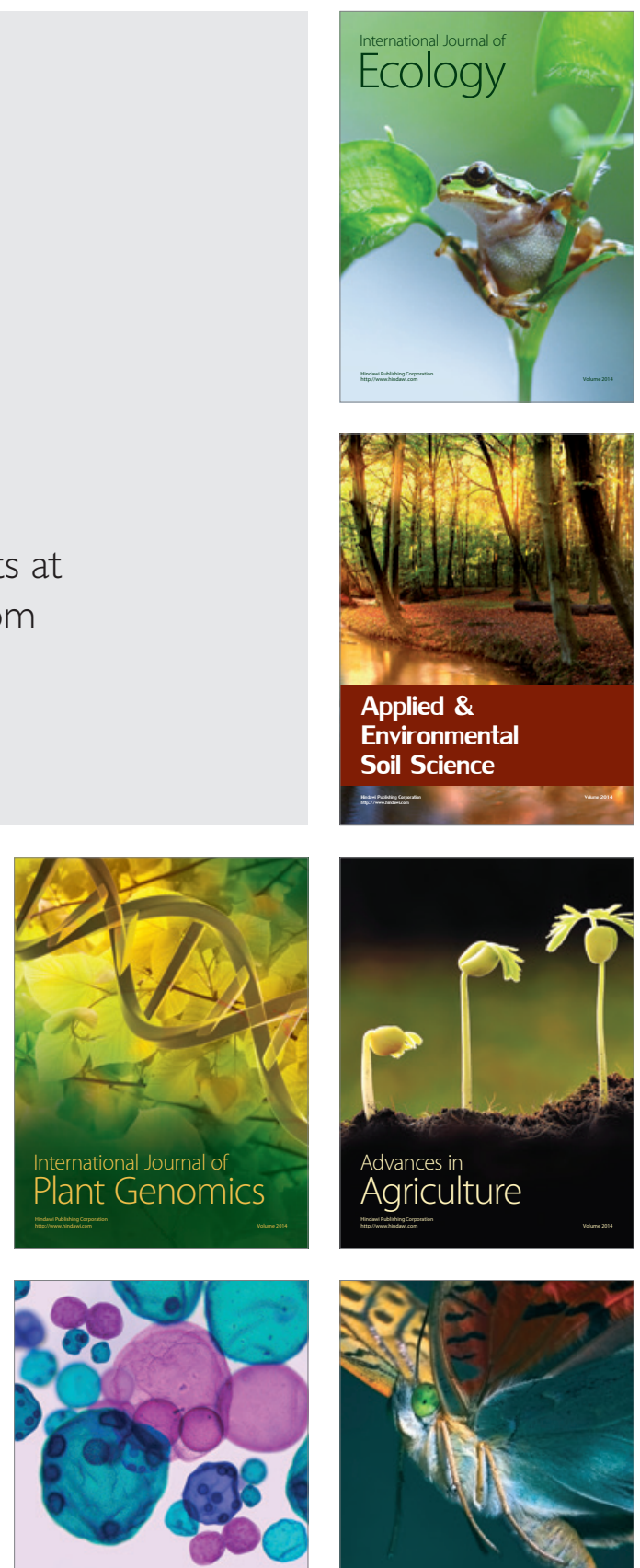

International Journal of Microbiology

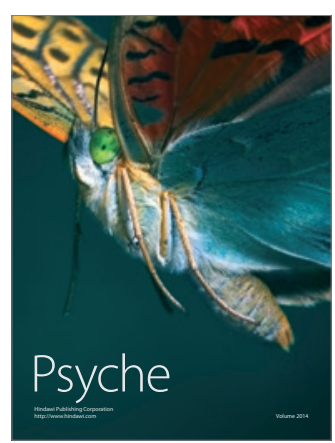

